\title{
AN OBJECTIVE EVALUATION OF TRANQUILLIZERS \\ AS PREANAESTHETIC MEDICATION: EFFECT ON ADRENOCORTICAL FUNCTION
}

\author{
Tsutomu Oyama, M.D., K. KimURA, M.D., T. TAKAZAWA, M.D., AND \\ H. TAKIGUCH, M.D. ${ }^{*}$
}

BeCAuse a large number of patients seem to be anxious before operation, ${ }^{1,2}$ understanding of the emotional problems of surgical patients by anaesthesiologists is important for the improvement of their care. Most workers ${ }^{3-5}$ have been in general agreement that the anxiety experienced by patients preoperatively causes no significant effect on the adrenocortical function. However, we recently found that preoperative apprehension as a stress does elicit adrenocortical stimulation judged by the peripheral plasma cortisol level. It was also demonstrated that the circulating cortisol level is a useful parameter for the objective evaluation of premedicating drugs. ${ }^{2}$

Due to differences in the species studied, the experimental design, and the validity of methods of analysis, there is considerable debate about the specific effect of tranquillizing drugs, reserpine and chlorpromazine, on the adrenocortical activity. ${ }^{6-8}$ The present study of 54 patients, therefore, was undertaken first to investigate the sedative effects of tranquillizing drugs such as hydroxyzine (Atarax, Vistaril), diazepam (Cercine, Horizone, Valium), and nitrazepam (Nelbon, Benzalin, Mogadon) in preoperative patients, and second to correlate subjective sedation by these agents with alterations in adrenocortical activity.

\section{METHODS}

Fifty-four patients who underwent operations were the subjects of the study. They ranged from 15 to 60 years of age and were free from endocrine, renal, and hepatic disease. The operations were scheduled to start at 9:00 AM. Premedication was administered by mouth at 8:00 PM on the day before operation and 7:00 AM on the day of operation, just after the first blood sampling. Eleven patients who served as a placebo group received 2 tablets of maltose. Hydroxyzine (2.5 $\mathrm{mg} / \mathrm{kg}$ ) was administered to 14 patients; 15 patients took diazepam $(0.2 \mathrm{mg} / \mathrm{kg})$ and 14 patients had nitrazepam $(0.2 \mathrm{mg} / \mathrm{kg})$. All received atropine $0.25 \mathrm{mg}$ intravenously and intramuscularly at 8:30 AM before induction and just after the last blood sampling. Subjective evaluations were made by asking whether the patients could sleep, had fear or concerns about their operations, or felt drowsy. These questionnaires were employed just prior to induction in the operating room, where the data were collected by the double-blind method.

- Dr. Oyama is Professor, and Drs. Kimura, Takazawa, and Takiguchi are Research Fellows, in the Department of Anaesthesiology, Hirosaki University, School of Medicine, Hirosaki, Aomori-Ken, Japan. 
Blood sampling times were 7:00 $\mathrm{AM}, 7: 30 \mathrm{AM}, 8: 00 \mathrm{AM}$ and 8:30 $\mathrm{AM}$ on the day before operation and on the day of operation. Three millilitres of venous blood were drawn into a syringe previously rinsed with heparin. The plasma was separated within 30 minutes in a centrifuge, and $1 \mathrm{ml}$ was used for free cortisol (17hydroxycorticosteroid $=17$-oHCs $=$ hydrocortisone) assay according to the method of Rudd ${ }^{9}$ using a Farrand spectrofluorimeter. The duplicate error of our method was $\pm 1.2 \mu \mathrm{g}$ per $100 \mathrm{ml}$ of plasma, and the recovery rate was 105 per cent which appears to be reliable for analysis of the data.

\section{Results}

\section{Placebo}

The subjective evaluation of the placebo patients is shown in Table I. Only two patients (18\%) felt tranquil in the operating room just prior to operation, and the remaining nine felt apprehension. The mean plasma cortisol level of these patients without any premedication at $7.00 \mathrm{AM}$ on the day preceding operation was $18.6 \pm 0.6 \mu \mathrm{g}$ ( $\pm=$ standard error of the mean), gradually decreasing with

TABLE I

Subjective Evaluation of the Premedicating Drugs

\begin{tabular}{|c|c|c|c|c|}
\hline State & Placebo & Hydroxyzine & Diazepam & Nitrazepam \\
\hline $\begin{array}{l}\text { Preoperative night's s } \\
\text { good } \\
\text { moderate } \\
\text { none }\end{array}$ & $\begin{array}{l}2(18.2) \\
3(27.3) \\
6(54.5)\end{array}$ & $\begin{array}{c}13(92.9) \\
1(7.1) \\
0(0)\end{array}$ & $\begin{array}{c}10(66.7) \\
4(26.7) \\
1(6.6)\end{array}$ & $\begin{aligned} & 11(78.6) \\
& 3(21.4) \\
& 0(0)\end{aligned}$ \\
\hline total & 11 & 14 & 15 & 14 \\
\hline $\begin{array}{l}\text { Apprehension just pri } \\
\text { tranquil } \\
\text { apprehensive } \\
\text { very apprehensive }\end{array}$ & $\begin{array}{l}\text { induction ( } \\
2(18.2) \\
7(63.6) \\
2(18.2)\end{array}$ & $\begin{array}{l}\text { AM) } \\
7(50.0) \\
6(42.9) \\
1(7.1)\end{array}$ & $\begin{array}{c}11(73.3) \\
4(26.7) \\
0(0)\end{array}$ & $\begin{array}{r}11(78.6) \\
3(21.4) \\
0(0)\end{array}$ \\
\hline total & 11 & 14 & 15 & 14 \\
\hline $\begin{array}{l}\text { Wakefulness just prio } \\
\text { drowsy } \\
\text { alert }\end{array}$ & $\begin{array}{c}\text { nduction }(8 \\
0 \\
11(100)\end{array}$ & $\begin{array}{l}8(57.1) \\
6(42.9)\end{array}$ & $\begin{array}{l}8(53.4) \\
7(46.6)\end{array}$ & $\begin{array}{r}12(85.7) \\
2(14.3)\end{array}$ \\
\hline total & 11 & 14 & 15 & 14 \\
\hline
\end{tabular}

Numbers in parentheses indicate percentages.

time as shown in Table II and Figure 1. The mean plasma cortisol levels on the day of operation decreased gradually except for the value at 8:30 AM, which was slightly higher $(1.0 \mu \mathrm{g})$ than the level of 8:00 AM. The differences in the plasma cortisol levels between the day of operation and the day preceding operation at each comparable time were not significant (Table II).

\section{Hydroxyzine}

About 50 per cent of the 14 patients who received hydroxyzine $(2.5 \mathrm{mg} / \mathrm{kg})$ felt tranquil in the operating room, although 93 per cent slept well through the 
oYAMA et al: TRANQULLIZZERS AS PREANAESTHETIC MEDICATION

TABLE II

Effect of Placebo on the Plasma Free Cortisol Levels ( $\mu \mathrm{g} / 100 \mathrm{ml}$ )

\begin{tabular}{|c|c|c|c|c|c|c|c|c|}
\hline \multirow{2}{*}{$\begin{array}{c}\text { Patient } \\
\text { no. }\end{array}$} & \multicolumn{4}{|c|}{ Preoperative day (AM) } & \multicolumn{4}{|c|}{ Operative day (AM) } \\
\hline & $7: 00$ & $7: 30$ & $8: 00$ & $8: 30$ & $7: 00$ & $7: 30$ & $8: 00$ & $8: 30$ \\
\hline 1 & 16.2 & 13.0 & 12.0 & 12.0 & 13.7 & 15.0 & 10.0 & 10.0 \\
\hline 2 & 19.1 & 15.5 & 14.5 & 10.9 & 19.1 & 12.1 & 13.6 & 10.0 \\
\hline 3 & 22.0 & 20.0 & 18.0 & 15.0 & 15.0 & 13.0 & 11.0 & 13.0 \\
\hline 4 & 16.6 & 11.6 & 15.4 & 10.9 & 18.1 & 9.0 & 12.5 & 15.0 \\
\hline 5 & 20.0 & 17.0 & 13.0 & 12.5 & 8.0 & 10.0 & 12.0 & 13.0 \\
\hline 6 & 20.5 & 21.3 & 19.6 & 17.1 & 16.3 & 16.3 & 14.6 & 15.5 \\
\hline 7 & 19.0 & 19.0 & 13.6 & 16.0 & 17.0 & 15.0 & 13.0 & 15.0 \\
\hline 8 & 17.0 & 15.0 & 12.0 & 10.0 & 15.0 & 12.0 & 12.0 & 10.0 \\
\hline 9 & 20.0 & 15.4 & 10.0 & 8.1 & 18.1 & 15.4 & 18.1 & 20.0 \\
\hline 10 & 15.7 & 14.3 & 21.4 & 10.7 & 17.2 & 11.4 & 20.0 & 21.4 \\
\hline 11 & 18.3 & 14.0 & 15.0 & 18.3 & 20.0 & 25.0 & 18.3 & 23.2 \\
\hline Mean & 18.6 & 16.0 & 15.0 & 12.9 & 16.1 & 14.0 & 14.1 & 15.1 \\
\hline $\mathrm{SE}$ & 0.6 & 0.8 & 1.0 & 1.0 & 1.0 & 1.2 & 1.2 & 1.1 \\
\hline$p^{*}$ & & & & & Ns ${ }^{\dagger}$ & NS & NS & NS \\
\hline
\end{tabular}

*Mean levels were compared from corresponding times of the preoperative and operative days. †NS $=$ Not significant.

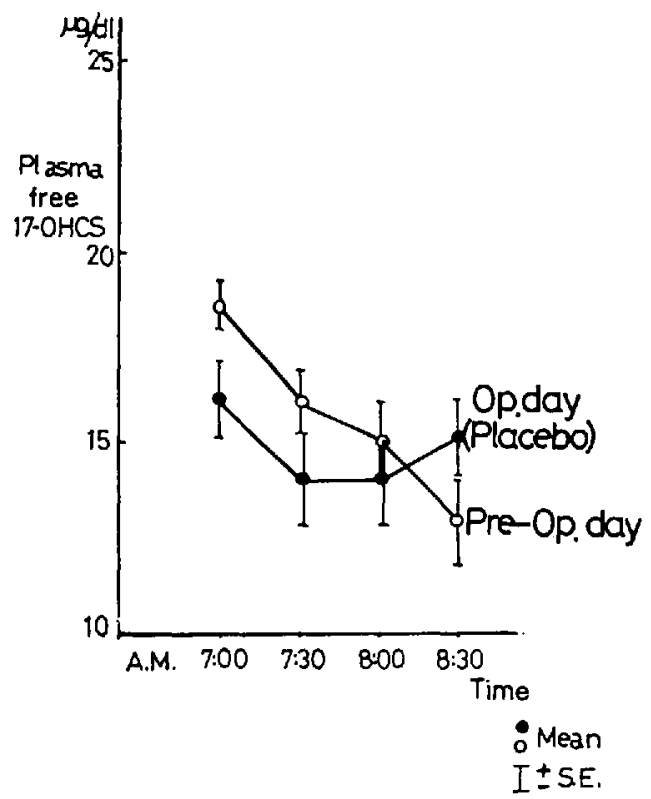

Figure 1. Mean plasma cortisol levels in patients receiving a placebo.

preoperative night. The mean plasma cortisol level significantly decreased at 7:00 AM on the day of operation (decrease $5.7 \mu \mathrm{g}, p<0.001$ ), 7:30 AM (decrease $2.4 \mu \mathrm{g}, p<0.005$ ), and 8:00 AM (decrease 2.6 $\mu \mathrm{g}, p<0.01$ ) in comparison with the values at corresponding times of the day preceding operation (Table III); but the reduction at 8:30 AM $(1.4 \mu \mathrm{g})$ was not significant. 
TABLE III

Effects of Hydroxyzine on the Plasma Free Cortisol Levels $(\mu \mathrm{g} / 100 \mathrm{ml}$ )

\begin{tabular}{|c|c|c|c|c|c|c|c|c|}
\hline \multirow{2}{*}{$\begin{array}{c}\text { Patient } \\
\text { no. }\end{array}$} & \multicolumn{4}{|c|}{ Preoperative day } & \multicolumn{4}{|c|}{ Operative day } \\
\hline & $7: 00$ & $7: 30$ & $8: 00$ & $8: 30$ & $7: 00$ & $7: 30$ & $8: 00$ & $8: 30$ \\
\hline 1 & 19.4 & 16.2 & 15.0 & 15.0 & 12.5 & 17.5 & 10.0 & 7.5 \\
\hline 2 & 20.0 & 23.3 & 21.3 & 16.6 & 17.3 & 18.6 & 18.0 & 16.6 \\
\hline 3 & 22.0 & 15.5 & 14.4 & 15.5 & 14.4 & 10.0 & 10.0 & 11.1 \\
\hline 4 & 24.0 & 20.0 & 19.0 & 13.0 & 14.0 & 16.0 & 15.0 & 14.0 \\
\hline 5 & 18.8 & 15.5 & 14.4 & 14.4 & 9.5 & 14.4 & 12.2 & 10.0 \\
\hline 6 & 17.7 & 15.5 & 15.5 & 14.4 & 13.3 & 11.1 & $12 . \overline{7}$ & 8.3 \\
\hline 7 & 15.0 & 11.6 & 10.0 & 10.0 & 8.3 & 10.0 & 11.6 & 13.3 \\
\hline 8 & 22.0 & 21.0 & 20.0 & 17.0 & 17.0 & 14.0 & 14.0 & 12.0 \\
\hline 9 & 22.7 & 15.1 & 13.6 & 13.1 & 20.4 & 15.0 & 12.7 & 12.7 \\
\hline 10 & 18.0 & 17.0 & 15.0 & 13.0 & 11.0 & 22.0 & 15.0 & 17.0 \\
\hline 11 & 17.2 & 17.2 & 15.7 & 14.3 & 14.3 & 17.2 & 17.2 & 18.6 \\
\hline 12 & 24.0 & 22.0 & 14.0 & 16.0 & 10.0 & 8.0 & 12.0 & 12.0 \\
\hline 13 & 20.0 & 20.0 & 15.0 & 10.0 & 17.5 & 10.0 & 15.0 & 16.0 \\
\hline 14 & 20.3 & 11.0 & 12.8 & 7.2 & 11.4 & 8.6 & 10.0 & 7.2 \\
\hline Mean & 21.1 & 16.4 & 15.1 & 14.0 & 15.4 & 14.0 & 12.5 & 12.6 \\
\hline SE & 0.7 & 0.8 & 0.9 & 0.6 & 1.1 & 1.0 & 0.8 & 1.0 \\
\hline$p$ & & & & & $<0.001$ & $<0.005$ & $<0.01$ & NS \\
\hline
\end{tabular}

\section{Diazepam}

Seventy-three per cent of 15 patients who received diazepam $(0.2 \mathrm{mg} / \mathrm{kg})$ felt tranquil in the operating room (Table I). The mean free cortisol levels in plasma on the day of operation were significantly reduced at 7:00 $\mathrm{AM}$ (decrease $3.4 \mu \mathrm{g}$, $p<0.01$ ), 7:30 AM (decrease 2.4 $\mu \mathrm{g}, p<0.02$ ), and 8:30 AM (decrease 1.6 $\mu \mathrm{g}$, $p<0.01)$ in comparison with the values at similar times of the day preceding operation (Table IV).

\section{Nitrazepam}

Eleven (78\%) of 14 patients to whom nitrazepam $(0.2 \mathrm{mg} / \mathrm{kg})$ was administered did not feel apprehension in the operating room (Table I). The mean free cortisol levels in plasma on the day of operation dccreased significantly at 7:00 AM (decrease $3.2 \mu \mathrm{g}, p<0.01$ ), 8:00 AM (decrease 3.9 $\mu \mathrm{g}, p<0.001$ ), and 8:30 AM (decrease $3.4 \mu \mathrm{g}, p<0.001$ ) in comparison with the levels at corresponding time on the day prior to operation (Table V and Fig. 2).

None of the cardiovascular or respiratory side-effects were observed in the four groups tested.

\section{Discussion}

The effects of hydroxyzine, diazepam, and nitrazepam on adrenocortical activity in man have not been reported previously. We found that these compounds definitely decreased preoperative emotional stress judged both by subjective evaluation and by significant reduction in the circulating plasma cortisol level in man. Therefore these tranquillizers seem to be useful anti-anxiety agents in preparing patients for anaesthesia and surgery. In accordance with its poor sedative effect ( 82 per cent felt apprehension), the placebo produced no significant influence 
OYAMA et al.: TRANQULLIZERS AS PREANAESTHETIC MEDICATION

TABLE IV

Effects of Diazepam on Plasma Free Cortisol Levels ( $\mu \mathrm{g} / 100 \mathrm{ml}$ )

\begin{tabular}{|c|c|c|c|c|c|c|c|c|}
\hline \multirow{2}{*}{$\begin{array}{c}\text { Patient } \\
\text { no. }\end{array}$} & \multicolumn{4}{|c|}{ Preoperative day } & \multicolumn{4}{|c|}{ Operative day } \\
\hline & $7: 00$ & $7: 30$ & $8: 00$ & $8: 30$ & $7: 00$ & $7: 30$ & $8: 00$ & $8: 30$ \\
\hline $\begin{array}{r}1 \\
2 \\
3 \\
4 \\
5 \\
6 \\
7 \\
8 \\
9 \\
10 \\
11 \\
12 \\
13 \\
14 \\
15\end{array}$ & $\begin{array}{l}20.0 \\
19.0 \\
23.1 \\
19.2 \\
21.7 \\
25.0 \\
17.0 \\
21.0 \\
16.7 \\
26.0 \\
19.0 \\
21.0 \\
21.0 \\
27.7 \\
10.0\end{array}$ & $\begin{array}{r}14.2 \\
18.5 \\
12.3 \\
17.5 \\
23.0 \\
17.1 \\
18.0 \\
17.0 \\
14.7 \\
22.0 \\
16.0 \\
16.5 \\
17.0 \\
23.8 \\
8.5\end{array}$ & $\begin{array}{r}11.7 \\
17.5 \\
10.8 \\
14.2 \\
18.6 \\
14.3 \\
13.5 \\
14.0 \\
14.0 \\
16.0 \\
13.0 \\
17.0 \\
12.0 \\
20.4 \\
7.7\end{array}$ & $\begin{array}{r}12.5 \\
11.0 \\
10.8 \\
11.7 \\
11.4 \\
11.4 \\
11.5 \\
12.0 \\
12.7 \\
14.0 \\
15.0 \\
16.0 \\
18.0 \\
12.3 \\
6.5\end{array}$ & $\begin{array}{r}17.5 \\
19.0 \\
18.3 \\
17.5 \\
23.0 \\
14.3 \\
12.0 \\
19.0 \\
16.0 \\
18.0 \\
16.0 \\
20.0 \\
22.0 \\
17.9 \\
6.5\end{array}$ & $\begin{array}{r}13.5 \\
10.0 \\
15.8 \\
14.2 \\
18.6 \\
13.0 \\
12.0 \\
19.0 \\
15.3 \\
20.0 \\
12.0 \\
17.0 \\
11.0 \\
20.8 \\
7.7\end{array}$ & $\begin{array}{r}7.8 \\
6.0 \\
12.8 \\
11.7 \\
15.7 \\
10.0 \\
10.0 \\
16.0 \\
12.6 \\
18.0 \\
10.5 \\
15.5 \\
19.0 \\
21.5 \\
7.7\end{array}$ & $\begin{array}{r}8.8 \\
6.0 \\
10.8 \\
9.2 \\
10.0 \\
8.6 \\
10.5 \\
13.0 \\
11.3 \\
12.0 \\
11.0 \\
16.0 \\
20.0 \\
9.2 \\
6.9\end{array}$ \\
\hline Mean & 20.5 & 17.1 & 14.3 & 12.5 & $17: 1$ & 14.7 & 13.0 & 10.9 \\
\hline $\mathbf{S E}$ & 1.1 & 1.0 & 0.8 & 0.7 & 1.0 & 1.0 & 1.1 & 0.9 \\
\hline$p$ & & & & & $<0.01$ & $<0.02$ & NS & $<0.01$ \\
\hline
\end{tabular}

TABLE $\mathrm{V}$

Effects of Nitrazepam on the Plasma Free Cortisol Levels ( $\mu \mathrm{g} / 100 \mathrm{ml}$ )

\begin{tabular}{|c|c|c|c|c|c|c|c|c|}
\hline \multirow{2}{*}{$\begin{array}{c}\text { Patient } \\
\text { no. }\end{array}$} & \multicolumn{4}{|c|}{ Preoperative day } & \multicolumn{4}{|c|}{ Operative day } \\
\hline & $7: 00$ & $7: 30$ & $8: 00$ & $8: 30$ & $7: 00$ & $7: 30$ & $8: 00$ & $8: 30$ \\
\hline $\begin{array}{r}1 \\
2 \\
3 \\
4 \\
5 \\
6 \\
7 \\
8 \\
9 \\
10 \\
11 \\
12 \\
13 \\
14\end{array}$ & $\begin{array}{l}20.8 \\
22.5 \\
18.3 \\
19.2 \\
25.3 \\
25.8 \\
25.0 \\
20.0 \\
20.0 \\
22.5 \\
27.0 \\
17.2 \\
17.2 \\
24.4\end{array}$ & $\begin{array}{l}11.6 \\
15.0 \\
21.7 \\
14.2 \\
26.5 \\
20.0 \\
19.0 \\
17.0 \\
14.0 \\
21.3 \\
25.0 \\
15.0 \\
15.8 \\
22.1\end{array}$ & $\begin{array}{l}11.6 \\
20.0 \\
13.3 \\
13.3 \\
24.1 \\
15.8 \\
18.0 \\
16.0 \\
15.0 \\
13.8 \\
18.0 \\
16.7 \\
15.0 \\
21.5\end{array}$ & $\begin{array}{r}11.6 \\
16.0 \\
13.3 \\
12.5 \\
27.0 \\
13.3 \\
17.0 \\
15.5 \\
14.0 \\
12.5 \\
15.0 \\
9.5 \\
15.0 \\
15.7\end{array}$ & $\begin{array}{l}20.0 \\
20.0 \\
11.7 \\
10.0 \\
27.6 \\
25.8 \\
20.4 \\
20.0 \\
14.0 \\
20.0 \\
22.0 \\
10.0 \\
18.4 \\
20.0\end{array}$ & $\begin{array}{l}10.0 \\
15.0 \\
11.7 \\
11.7 \\
25.9 \\
23.3 \\
18.0 \\
16.0 \\
11.0 \\
17.5 \\
17.0 \\
19.2 \\
15.0 \\
15.0\end{array}$ & $\begin{array}{l}11.6 \\
12.5 \\
13.3 \\
10.8 \\
23.9 \\
11.7 \\
12.0 \\
14.0 \\
10.0 \\
11.2 \\
12.0 \\
10.0 \\
14.2 \\
11.3\end{array}$ & $\begin{array}{r}10.8 \\
12.5 \\
11.7 \\
12.5 \\
22.9 \\
10.0 \\
10.0 \\
12.0 \\
8.0 \\
8.7 \\
11.0 \\
10.0 \\
8.4 \\
13.4\end{array}$ \\
\hline Mean & 21.8 & 18.5 & 16.6 & 14.9 & 18.6 & 16.2 & 12.7 & 11.5 \\
\hline SE & 0.9 & 1.2 & 0.9 & 1.1 & 1.5 & 1.3 & 1.0 & 0.7 \\
\hline$p$ & & & & & $<0.01$ & NS & $<0.001$ & $<0.001$ \\
\hline
\end{tabular}

on the peripheral circulating cortisol level in preoperative patients (Tables I and II).

As previously reported, ${ }^{2}$ it is important to compare values for premedicated patients with those for the same subjects without premedication at the same time in the morning, since because of diurnal variation, plasma levels of free cortisol 


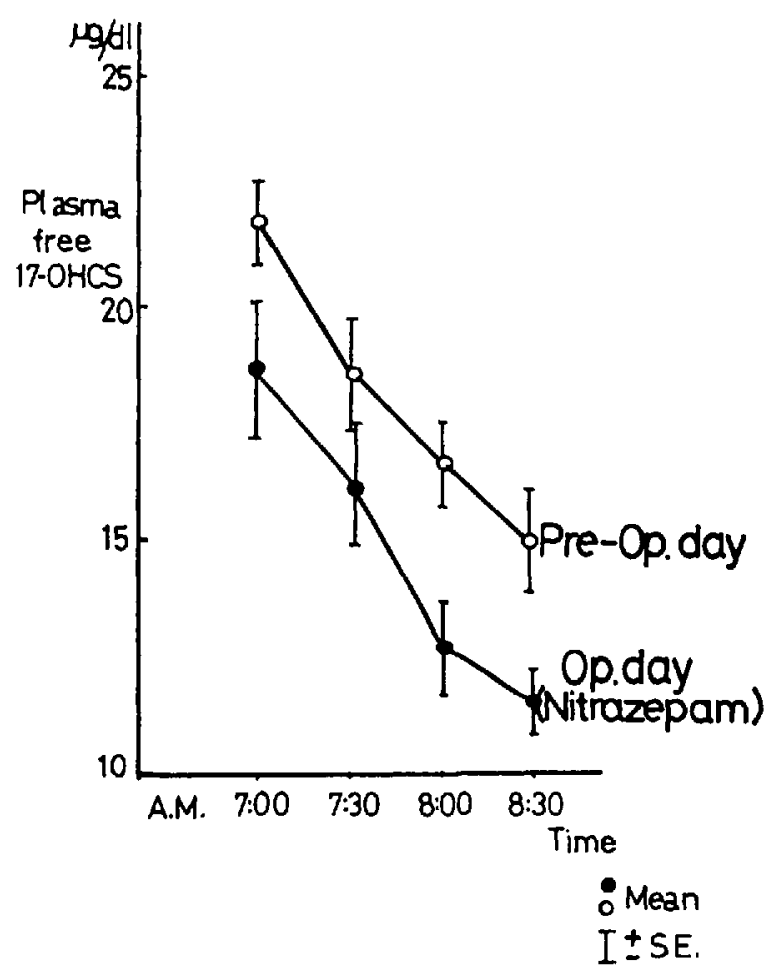

Figure 2. Mean plasna cortisol levels in patients receiving nitrazepam.

decrease as time passes in the moming. Therefore, the comparison of values in the same patients between 7:00 AM (before premedication), and 8:30 AM (after premedication) on the same day has little meaning. This might explain why Virtue et $a l^{4}$ and Hammond et al., ${ }^{3}$ without considering diurnal variation, could not find any significant alteration in the peripheral plasma cortisol levels in the preoperative period with or without premedication.

Hydroxyzine (Atarax, Vistaril), a derivative of both diphenylmethane and piperazine which is chemically unrelated to phenothiazine, has been used for premedication. ${ }^{10}$ The efficacy of this compound $(2.5 \mathrm{mg} / \mathrm{kg})$ in reducing preoperative fear and tension was noted in half of the patients treated, which correlated with the significant decrease in plasma cortisol level within one hour of administration (Table III), but the cortisol level after 1/1/2 hours (8:30 AM) was not significantly reduced. This would imply that hydroxyzine should be given at least one hour prior to the start of anaesthesia.

Diazepam (Cercine, Valium; 7-chloro-1,3-dihydro-1-methyl-5-phenyl-2H-1,4benzodiazepine-2-one) and nitrazepam (Nelbon; 1,3-dihydro-7-nitro-5-phenyl$2 \mathrm{H}$-1,4-benzodiazepine-2-one) are both derivatives of benzodiapine like chlordiazepoxide (Contol). These agents have ataractic effects without extrapyramidal side-effects or autonomic blocking. ${ }^{12-14}$ We observed that the patients treated by these compounds were not apprehensive and were relaxed in the operating room before anaesthesia (73-78\%). The sleeping tendency was the strongest in the 
nitrazepam group (Table I). In correlation with the calming effect, the mean cortisol levels in plasma on the day of operation were significantly reduced in patients treated with these compounds in comparison with the values at similar times on the day before operation (Tables IV, V).

There is considerable confusion in the literature on the pituitary-adrenal blockading effect of tranquillizing compounds, because they may elicit an initial stimulatory response and inhibitory effects after repeated administration judged by the adrenal ascorbic depletion response to subsequent stressful stimuli in animals. ${ }^{6-8}$ Cristy et al. ${ }^{15}$ reported a diminished adrenocortical response to insulin hypoglycaemia in chlorpromazine-treated patients; Gold et al. ${ }^{16}$ observed that chlorpromazine decreased the response to injections of metyrapone (su-4885), although the response to operation was unaffected. Sloane et al. ${ }^{17}$ suggested that the inhibitory effect of chlorpromazine on adrenocortical responses in man is due to a moderately decreased adrenal sensitivity to ACTH, rather than to inhibition of ACTH secretion. The pituitary-adrenal response to surgical stress does not seem to be affected by treatment with chlorpromazine, ${ }^{6,16}$ but when a patient has been receiving large doses of the drug for a long period of time it might be wise to check his response to a test dose of ACTH before operation, because a single administration of the tested tranquillizers depressed adrenocortical function in our study.

\section{SUMMARY AND CONCLUSIONS}

The present study was undertaken to evaluate the tranquillizers objectively as premedicating drugs. The sedative effects of placebo, hydroxyzine $(2.5 \mathrm{mg} / \mathrm{kg})$, diazepam $(0.2 \mathrm{mg} / \mathrm{kg})$ and nitrazepam $(0.2 \mathrm{mg} / \mathrm{kg})$ were judged both subjectively by the double-blind method and objectively by measurement of free cortisol levels in the plasma of 54 patients.

These agents were administered by mouth at 8:00 PM on the day before operation and at 7:00 AM on the day of operation just after the first blood sampling. In order to avoid the diurnal variation in the plasma cortisol level, the plasma levels of the same patients at 7:00,7:30,8:00, and 8:30 AM on the previous day served as controls to the values at corresponding times on the operative day.

While placebo had no measurable effects, diazepam and nitrazepam clearly decreased plasma free cortisol levels at 8:30 AM and hydroxyzine significantly reduced the value at 8:00 $\mathrm{AM}$. The sedative effects of these tranquillizing agents and the ineffectiveness of the placebo definitely correlated with the alterations in plasma cortisol levels. The clinical application of these findings was also discussed.

\section{RÉSUMÉ}

Ce travail a été fait pour évaluer objectivement les tranguillisants comme agents de prémédication. Les effects sédatifs du placebo, de l'hydroxyzine (2.5 $\mathrm{mg} / \mathrm{kg})$, du diazépam $(0.2 \mathrm{mg} / \mathrm{kg})$ et du nitrazépam $(0.2 \mathrm{mg} / \mathrm{kg})$ ont été évalués subjectivement par la méthode à double inconnu et objectivement en mesurant les niveaux de cortisol libre dans le plasma de 54 malades.

Ces agents ont été administrés par la bouche à 8:00 heures PM la veille de 
l'opération et à 7:00 heures AM le jour de l'opération, immédiatement après le premier prélèvement de sang. Pour éviter la variation diurne dans le niveau de cortisol du plasma, les niveaux plasmatiques des mêmes malades à 7:00, 7:30, 8:00 et 8:30 heures AM le jour précédent ont servi de contrôle pour les résultats aux mêmes heures le jour de l'opération.

Alors que le placebo n'a pas eu d'effets appréciables, le diazépam et le nitrazépam ont diminué clairement les niveaux de cortisol libre à 8:30 heures AM et l'hydroxymine a réduit sensiblement le niveau à 8:00 heures AM. Les effets sédatifs de ces tranquillisants et l'absence d'effet du placebo ont été définitivement en corrélation avec les changements de niveaux du cortisol plasmatique. On a aussi étudié l'application clinique de ces constatations.

\section{REFERENCES}

1. Norris, W. \& BaxpD, W. L. M. Pre-operative Anxiety: A Study of the Incidence and Aetiology. Brit. J. Anaesth. 39: 503 (1967).

2. Oyama, T; Shibata, S.; Kumura, K.; \& Takazawa, T. An Objective Evaluation of Pentobarbital as Preanesthetic Medication: Effect on Adrenocortical Function. Anesth. \& Analg. (in press, 1969).

3. Hammond, W. G.; Vandam, L. D.; Davis, J. M.; Carter, R. D.; Ball, M. R.; \& Moore, F. D. Studies in Surgical Endocrinology: IV. Anesthetic Agents as Stimuli to Change in Corticosteroids and Metabolism. Ann. Surg. 148: 199 (1958).

4. Virtue, R. W.; Helmreich, M. L.; \& Gainza, E. The Adrenal Cortical Response to Surgery: I. The Effect of Anesthesia on Plasma 17-hydroxy Corticosteroid Levels. Surgery. 41: 549 (1957).

5. VANDAM, L. D. \& Moore, F. D. Adrenocortical Mechanism Related to Anesthesia. Anesthesiology. 21: 513 (1960).

6. VAN Brunt, E. E. \& Ganong, W. F. The Effects of Preanesthetic Medication, Anesthesia and Hypothermia on the Endocrine Response to Injury. Anesthesiology. 24: 500 (1963).

7. Way, E. L. \& Sutherrand, V. C. Pharmacologically Active Brain Substances and Their Relation to Endocrine Effects. Anesthesiology. 24: 543 (1963).

8. De WIED, D. Chlorpromazine and Endocrine Function. Pharmacol. Rev. 19: 251 (1967).

9. RudD, B. T.; SAMPson, P.; \& BRooke, N. A New Flurometric Method of Plasma Cortisol Assay with a Study of Pituitary-adrenal Function Using Metyrapone (sv 4885). J. Endocrin. 27: 317 (1963).

10. Lear, E.; Suntay, R.; Fisch, H.; Chiron, A. E.; \& Pallin, I. M. Ataraxic Drugs in Preanesthetic Medication. Blind Studies in 1,852 Patients. Anesthesiology. 22: 529 (1961).

11. Tornetta, F. J. Diazepam as Preanesthetic Medication: A Double-blind Study. Anesth. \& Analg. 44: 449 (1965).

12. Brandt, A. L. \& OAkEs, F. D. Preanesthesia Medication: Double-blind Study of a New Drug, Diazepam. Anesth. \& Analg. 44: 125 (1965).

13. Randali, L. O.; Schallek, W.; Scheckel, C.; Bagdon, R. E.; \& Rieder, J. Zur Pharmakologie von Mogadon, einem Schlafmittel mit neuartigem Wirkungsmechanismus. Schweiz. med. Wchnschr. 95: 334 (1965).

14. ALdER, A. Mogadon in der Narkoseprämedikation. Praxis. 54: 365 (1965).

15. Christy, N. P.; Longson, D.; Horwitz, W. A.; \& KNIGHT, M. M. Inhibitory Effect of Chlorpromazine upon the Adrenal Cortical Response to Insulin Hypoglycemia in Man. J. Clin. Invest. 36: 543 (1957).

16. Gold, E. M.; Di Ratmondo, V. C.; Kent, J. R.; \& Forsham, P. H. Comparative Effects of Certain Non-narcotic Central Nervous System Analgesics and Muscle Relaxants on the Pituitary Adrenocortical System. Ann. New York Acad. Sc. 86: 178 (1960).

17. Sloane, R. B.; Saffran, M.; \& Cleghorn, R. A. Steroid Response to acth and the Effect of Ataractic Drugs. In: Psychoendocrinology, ed. M. Reiss. New York: Grune \& Stratton (1958). 